\title{
Saccharopolyspora antimicrobica sp. nov., an actinomycete from soil
}

\author{
Li-Jie Yuan, ${ }^{1} \dagger$ Yu-Qin Zhang, ${ }^{1,2}+$ Yan Guan, ${ }^{1}$ Yu-Zhen Wei, ${ }^{1}$ Qiu-Ping Li, ${ }^{1}$ \\ $\mathrm{Li}-Y a n \mathrm{Yu},{ }^{1}$ Wen-Jun $\mathrm{Li}^{2}$ and Yue-Qin Zhang ${ }^{1}$ \\ ${ }^{1}$ Institute of Medicinal Biotechnology, Chinese Academy of Medical Sciences and Peking Union \\ Medical College, Beijing 100050, PR China \\ ${ }^{2}$ The Key Laboratory for Microbial Resources of the Ministry of Education, PR China, and \\ Laboratory for Conservation and Utilization of Bio-Resources, Yunnan Institute of Microbiology, \\ Yunnan University, Kunming, Yunnan 650091, PR China
}

\author{
Correspondence \\ Wen-Jun Li \\ wjli@ynu.edu.cn \\ Yue-Qin Zhang \\ zyq_0525@yahoo.com.cn
}

The genus Saccharopolyspora was proposed by Lacey \& Goodfellow (1975) to accommodate actinomycetes from sugar cane bagasse that produced white aerial mycelia with bead-like chains of spores enclosed in a characteristic hairy sheath. The genus encompasses aerobic, non-acid-fast organisms which form extensively branched substrate hyphae that fragment into rod-shaped elements and aerial hyphae that segment into bead-like chains of spores. The chemical properties of the genus Saccharopolyspora include a pattern of meso-diaminopimelic acid, arabinose and

†These authors contributed equally to the work.

The GenBank/EMBL/DDBJ accession number for the 16S rRNA gene sequence of strain 105-00074 ${ }^{\top}$ is EF693956.

Tables giving the cellular fatty acid profiles of strains $105-00074^{\top}, 105-$ 00051 and 103-00808 and levels of DNA-DNA relatedness among these three novel strains and reference strains Saccharopolyspora hirsuta subsp. hirsuta DSM $43463^{\top}$ and Saccharopolyspora spinosa DSM $44228^{\top}$ are available with the online version of this paper. galactose in the cell-wall peptidoglycan that lacks mycolic acids (Embley et al., 1987; Goodfellow et al., 1989), the presence of iso-branched and anteiso-branched-chain fatty acids (Embley et al., 1987, 1988; Goodfellow et al., 1989), major amounts of phosphatidylglycerol, phosphatidylcholine, phosphatidylethanolamine and phosphatidylmethylethanolamine (a type PIII phospholipid pattern) (Lechevalier et al., 1977) and MK-9 $\left(\mathrm{H}_{4}\right)$ as the predominant menaquinone (Embley et al., 1987; Goodfellow et al., 1989). The DNA G $+\mathrm{C}$ contents of members of the genus are in the range $66-77 \mathrm{~mol} \%$ (Goodfellow et al., 1989). At the time of writing, the genus Saccharopolyspora comprises ten recognized species, namely Saccharopolyspora erythraea (Labeda, 1987), S. flava (Lu et al., 2001), S. gregorii (Goodfellow et al., 1989), S. hirsuta (Lacey \& Goodfellow, 1975), S. hordei (Goodfellow et al., 1989), S. rectivirgula (Korn-Wendisch et al., 1989), S. spinosa (Mertz \& Yao, 1990), S. spinosporotrichia (Zhou et al., 1998), S. taberi (Korn-Wendisch et al., 1989) and S. thermophila (Lu et al., 2001). 
During the course of a screening programme to identify new antibiotics, strains I05-00051, I05-00074 ${ }^{\mathrm{T}}$ and $\mathrm{I} 03-$ 00808 were isolated from soil samples collected from Beijing and Sichuan, China, by using yeast extract-malt extract agar medium (ISP 2; Shirling \& Gottlieb, 1966), incubated at $28{ }^{\circ} \mathrm{C}$ for 21 days. These three strains were maintained on ISP 2 agar slants at $4{ }^{\circ} \mathrm{C}$ and as glycerol suspensions $(20 \%, \mathrm{v} / \mathrm{v})$ at $-20{ }^{\circ} \mathrm{C}$. Biomass for molecular systematic and chemotaxonomic studies was obtained after incubation in shake flasks of trypticase soy broth medium (Difco) at $28{ }^{\circ} \mathrm{C}$ for $4-7$ days.

Aerial spore-mass colour, substrate mycelial pigmentation and the production of diffusible pigments were observed on ISP 2, ISP 3, ISP 4, ISP 5 (Shirling \& Gottlieb, 1966), Czapek solution agar (Waksman, 1961), nutrient agar (Difco) and potato agar (Waksman, 1961) media following incubation at $28{ }^{\circ} \mathrm{C}$ after 7, 14, 21 and 28 days. Sporechain morphology was recorded by examining gold-coated dehydrated specimens of 28-day cultures grown on ISP 2 agar with a scanning electron microscope (Quanta; FEI). The coverslip technique (Zhou et al., 1998) was used to observe the hyphae and spore-chain characteristics.

All the following experiments for the three novel strains were carried out with S. hirsuta subsp. hirsuta DSM $43463^{\mathrm{T}}$ and S. spinosa DSM $44228^{\mathrm{T}}$ as controls. Growth temperature was tested at $0,4,10,15,20,28-37$ (at intervals of $\left.0.5{ }^{\circ} \mathrm{C}\right), 40,45$ and $55{ }^{\circ} \mathrm{C}$ on ISP 2 . The ability of the strains to grow at different $\mathrm{pH}$ values (5.0-11.0) (at intervals of 0.5 $\mathrm{pH}$ units) and $\mathrm{NaCl}$ concentrations $(0-20 \%$, w/v) (at intervals of $0.5 \%$ ) was examined on ISP 2 as basal medium. Carbon source utilization tests and qualitative enzyme tests were determined by using API $50 \mathrm{CH}$ and API ZYM test kits. Hydrolysis of urea was determined on peptoneglucose agar comprising (per litre distilled water): $1 \mathrm{~g}$ peptone, $1 \mathrm{~g}$ glucose, $5 \mathrm{~g} \mathrm{NaCl}$ and $2 \mathrm{~g} \quad \mathrm{KH}_{2} \mathrm{PO}_{4}$, supplemented with $2 \%(\mathrm{w} / \mathrm{v})$ urea and $0.001 \%(\mathrm{w} / \mathrm{v})$ phenol red. Hydrolysis of starch was determined on peptone-beef extract agar containing $0.2 \%(\mathrm{w} / \mathrm{v})$ soluble starch by flooding of the plates with iodine solution. Hydrolysis of casein was tested on casein agar by observation of clear zones around the colonies. The incubation period for hydrolysis of urea, starch and casein was 4 days at $28{ }^{\circ} \mathrm{C}$. Gelatin hydrolysis was determined by incubation for 3 weeks at $28{ }^{\circ} \mathrm{C}$ on peptone-gelatin medium (per litre distilled water: $5 \mathrm{~g}$ peptone and $120 \mathrm{~g}$ gelatin). Milk coagulation and peptonization were determined by using $20 \%$ (w/v) skimmed milk as the medium with incubation for 3 weeks at $28{ }^{\circ} \mathrm{C}$. Susceptibility to lysozyme and antibiotics was determined by using the discdiffusion plate method. The following antibiotics were tested (concentration per millilitre in parentheses) on tryptone soy agar (TSA; Oxoid) medium: amikacin $(30 \mu \mathrm{g})$, aureomycin $(30 \mu \mathrm{g})$, ciprofloxacin $(10 \mu \mathrm{g})$, chloramphenicol $(30 \mu \mathrm{g})$, erythromycin $(15$ and $30 \mu \mathrm{g})$, gentamicin sulfate $(10 \mu \mathrm{g})$, kanamycin $(15 \mu \mathrm{g})$, netilmicin $(10 \mu \mathrm{g})$, novobiocin $(5$ and $30 \mu \mathrm{g})$, oleandomycin $(10 \mu \mathrm{g})$, penicillin $\mathrm{G}(10 \mathrm{U})$, polymyxin $\mathrm{B}(10$ and
$300 \mathrm{U})$, streptomycin sulfate (10 and $25 \mu \mathrm{g}$ ), terramycin $(2.5$ and $30 \mu \mathrm{g})$, tetracycline $(10$ and $30 \mu \mathrm{g})$, tobramycin sulfate $(10 \mu \mathrm{g})$ and vancomycin $(10 \mu \mathrm{g})$. The antimicrobial activities of strains I05-00051, I05-00074 ${ }^{\mathrm{T}}$ and I03-00808 were investigated by using media containing Staphylococcus aureus, Escherichia coli and Mycobacterium smegmatis (all at $10^{8}$ c.f.u. $\mathrm{ml}^{-1}$ ).

Strains I05-00051, I05-00074 ${ }^{\mathrm{T}}$ and I03-00808 developed well on the test media, including ISP 2, ISP 3, ISP 4, ISP 5, potato agar, Czapek's agar and nutrient agar. Vegetative hyphae were long and well developed. Buff, pink to brown diffusible pigments were produced when strains I05-00051, I05-00074 $4^{\mathrm{T}}$ and I03-00808 were grown on the above media for 7, 14 and 21 days. Aerial mycelia developed well with long spore chains. All spores were non-motile and roughsurfaced (Fig. 1). Good growth occurred at $28-37{ }^{\circ} \mathrm{C}$ and at pH 7-7.5 with 0-7\% (w/v) NaCl. Detailed physiological and biochemical characteristics of strain $\mathrm{I} 05-00074^{\mathrm{T}}$ are given in Table 1 and in the species description below. Strains I05-00051, I05-00074 ${ }^{\mathrm{T}}$ and I03-00808 produced a substance that inhibited growth of Staphylococcus aureus and E. coli.

The whole-cell sugar pattern and the diagnostic isomers of diaminopimelic acid were determined by TLC (Lechevalier \& Lechevalier, 1965, 1980). Menaquinones were extracted and analysed by using the method of Collins (1985). Phospholipids were extracted and identified as described by Minnikin et al. (1984). The resultant fatty acids were prepared and analysed following the standard Sherlock MIDI (Microbial Identification) system (Sasser, 1990; Kämpfer \& Kroppenstedt, 1996).

Arabinose and galactose were detected as the major components of sugars in the whole-cell hydrolysates of strains I05-00051, I05-00074 ${ }^{\mathrm{T}}$ and I03-00808 with very small amounts of ribose and glucose. mesoDiaminopimelic acid was the diagnostic diamino acid in the cell-wall peptidoglycan. The phospholipids comprised

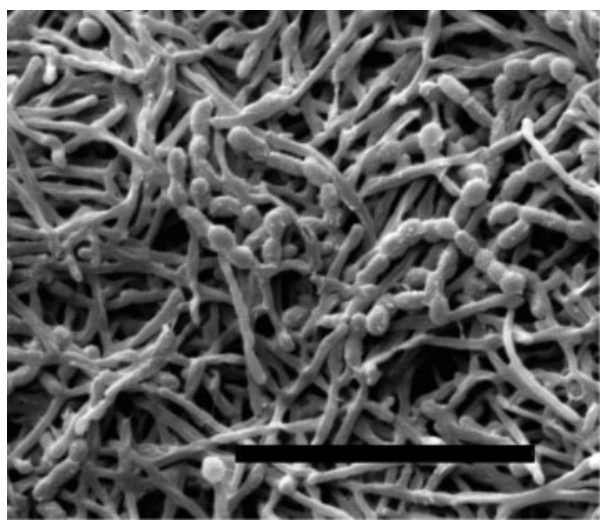

Fig. 1. Scanning electron micrograph showing vesicular chains of rough-surfaced spores of a 28-day-old culture of strain 105$00074^{\top}$ grown on ISP medium 2 at $28^{\circ} \mathrm{C}$. Bar, $10 \mu \mathrm{m}$. 
Table 1. Differential phenotypic characteristics between strain $105-00074^{\top}$ and the type strains of recognized species of the genus Saccharopolyspora

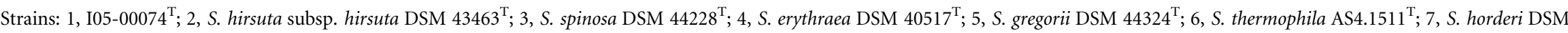
$44065^{\mathrm{T}}$; 8, S. rectivirgula DSM $43747^{\mathrm{T}} ; 9$, S. flava AS4.1520 ${ }^{\mathrm{T}} ; 10$, S. spinospirotrichia DSM $44350^{\mathrm{T}} ; 11$, S. taberi DSM $43856^{\mathrm{T}}$. Data for strain I05-00074 $4^{\mathrm{T}}$, S. hirsuta subsp. hirsuta DSM $43463^{\mathrm{T}}$ and S. spinosa DSM $44228^{\mathrm{T}}$ are from the present study; other data are taken from Korn-Wendisch et al. (1989) and Lu et al. (2001). BF, Buff; BR, brown; C, colourless; G, grey; O, orange; P, pink; R, red; W, white; Y, yellow; +, positive; -, negative; NA, not applicable (aerial mycelium was not observed); ND, not determined.

\begin{tabular}{|c|c|c|c|c|c|c|c|c|c|c|c|}
\hline Characteristic & 1 & 2 & 3 & 4 & 5 & 6 & 7 & 8 & 9 & 10 & 11 \\
\hline Spore arrangement & Straight & $\begin{array}{l}\text { Straight to } \\
\text { loose spirals }\end{array}$ & $\begin{array}{l}\text { Hooks and } \\
\text { open loops }\end{array}$ & Open spirals & $\begin{array}{c}\text { Hooks/flexuous } \\
\text { hyphae }\end{array}$ & $\begin{array}{c}\text { Hooks/flexuous } \\
\text { hyphae }\end{array}$ & $\begin{array}{l}\text { Hooks and } \\
\text { spirals }\end{array}$ & Straight & Straight & Spirals & $\mathrm{NA}$ \\
\hline Spore ornamentation & Rough & Hairy & Spiny & Spiny & Smooth & Smooth & Smooth & $\begin{array}{l}\text { Smooth or irregularly } \\
\text { rough }\end{array}$ & Smooth & Spiny & $\mathrm{NA}$ \\
\hline Substrate mycelium & Branched & Branched & Branched & Branched & Fragments & Fragments & Fragments & Branched & Fragments & Fragments & Fragments \\
\hline \multicolumn{12}{|l|}{ Colour of: } \\
\hline Aerial mycelium & $\mathrm{w}$ & $\mathrm{w}$ & $\mathrm{W}-\mathrm{P}$ & P-BRG-W & $W-Y$ & $\mathrm{w}$ & $\mathrm{W}-\mathrm{Y}$ & W-light $\mathrm{P}$ & $\mathrm{w}$ & $W-G$ & $\mathrm{NA}$ \\
\hline Substrate mycelium & W-BF-P & $\mathrm{C}-\mathrm{BF}$ & G-OY-BR & OY-RBR & $\mathrm{C}-\mathrm{BF}$ & $\mathrm{C}-\mathrm{BF}$ & $\mathrm{C}-\mathrm{BF}$ & $\mathrm{Y}-\mathrm{O}$ & Y & BR-R & $\mathrm{C}-\mathrm{Y}$ \\
\hline Soluble pigment & BF-P-BR & $\mathrm{R}-\mathrm{O}-\mathrm{Y}$ & $\mathrm{C}-\mathrm{BR}$ & Y-POBR & None & None & None & None & None & $\mathrm{BR}$ & $\mathrm{O}-\mathrm{R}$ \\
\hline $\begin{array}{l}\text { Spores on substrate } \\
\text { mycelium }\end{array}$ & - & - & - & - & - & - & - & + & - & - & - \\
\hline \multicolumn{12}{|l|}{ Degradation of: } \\
\hline Adenine & + & + & - & + & - & + & + & - & + & - & + \\
\hline Casein & + & + & - & - & + & - & + & - & - & + & + \\
\hline Chitin & - & - & - & + & - & - & + & - & - & - & + \\
\hline Elastin & - & + & - & + & + & - & + & - & - & + & + \\
\hline Starch & + & + & - & + & + & + & + & + & + & + & + \\
\hline Tyrosine & + & + & + & + & + & + & + & + & - & - & + \\
\hline Xanthine & - & + & + & + & + & - & + & + & + & + & + \\
\hline Reduction of nitrate & + & - & + & + & - & - & - & + & + & - & + \\
\hline $\mathrm{NaCl}$ tolerance $(\mathrm{w} / \mathrm{v})$ & $\leqslant 7$ & $<7$ & $<11$ & $<5$ & 13 & 7 & $<13$ & $<10$ & 7 & $2-3$ & 7 \\
\hline Temperature range $\left({ }^{\circ} \mathrm{C}\right)$ & $20-45$ & $25-50$ & $15-37$ & $20-42$ & $10-35$ & $45-55$ & $20-60$ & $37-63$ & $28-37$ & $28-37$ & $20-45$ \\
\hline \multicolumn{12}{|c|}{ Utilization of carbohydrates as sole carbon source } \\
\hline L-Arabinose & + & - & - & + & + & - & + & - & - & - & - \\
\hline D-Galactose & + & + & + & + & + & + & + & + & + & + & + \\
\hline D-Lactose & + & + & + & - & - & + & + & + & + & - & + \\
\hline Maltose & + & + & + & + & + & + & + & + & + & + & + \\
\hline Raffinose & + & + & + & + & + & + & + & + & + & + & + \\
\hline L-Rhamnose & + & + & + & + & + & + & + & + & + & + & + \\
\hline Sucrose & + & + & + & + & + & + & + & + & + & + & + \\
\hline D-Xylose & + & + & - & + & + & + & + & + & + & + & + \\
\hline
\end{tabular}


diphosphatidylglycerol, phosphatidylcholine, phosphatidylglycerol and phosphatidylinositol. The predominant menaquinone was MK-9 $\left(\mathrm{H}_{4}\right)$; MK- $9\left(\mathrm{H}_{2}\right)$ and MK-9 $\left(\mathrm{H}_{6}\right)$ were detected as minor components. The detailed cellular fatty acid profiles of strains I05-00051, I05-00074 ${ }^{\mathrm{T}}$ and I0300808 are given in Supplementary Table S1 in IJSEM Online; iso- $\mathrm{C}_{15: 0}$, iso- $\mathrm{C}_{16: 0,}$, iso- $\mathrm{C}_{17: 0}$ and anteiso- $\mathrm{C}_{17: 0}$ were the major fatty acids.

Extraction of genomic DNA and amplification of the $16 \mathrm{~S}$ rRNA gene were performed as described by Li et al. (2007). Purified PCR products were sequenced by using an ABI PRISM automatic sequencer (model 3730XL). The 16S rRNA gene sequences were aligned with available nucleotide sequences of members of the genus Saccharopolyspora and related genera retrieved from the DDBJ/GenBank/ EMBL databases by using the CLUSTAL_X 1.8 program (Thompson et al., 1997) based on the BLAST results in NCBI. Subsequently, a phylogenetic analysis was performed by using MEGA version 2.1 (Kumar et al., 2001). Distances were calculated according to the Kimura twoparameter model (Kimura, 1980, 1983) and clustering was performed with the neighbour-joining method (Saitou \& Nei, 1987). Levels of $16 \mathrm{~S}$ rRNA gene sequence similarity were recalculated by using a web-based tool in http:// www.eztaxon.org as described by Chun et al. (2007). Bootstrap analysis (1000 resamplings) was used to evaluate the tree topology of the neighbour-joining data (Felsenstein, 1985).

Levels of DNA-DNA relatedness among the three test strains and reference strains S. hirsuta subsp. hirsuta DSM $43463^{\mathrm{T}}$ and S. spinosa DSM $44228^{\mathrm{T}}$ were determined according to the thermal renaturation method (De Ley et al., 1970), by using a UV-1700 spectrophotometer (Shimadzu) equipped with a DCW-2008 thermo bath. The $\mathrm{G}+\mathrm{C}$ content of the genomic DNA was determined by using the thermal denaturation $\left(T_{\mathrm{m}}\right)$ method (Marmur \& Doty, 1962) with E. coli AS1.365 as a control.

The almost-complete 16S rRNA gene sequences of strains I05-00051, I05-00074 ${ }^{\mathrm{T}}$ and $\mathrm{I} 03-00808$ were generated.
Levels of sequence similarity among these three strains were above $99.0 \%$. Comparison of their nucleotide sequences with those of representatives of the families Actinosynnemataceae and Pseudonocardiaceae and related taxa (Labeda \& Kroppenstedt, 2000) clearly showed that the three isolates belonged to the genus Saccharopolyspora. In the phylogenetic tree constructed based on 16S rRNA gene sequences (Fig. 2), the three organisms were included in the clade comprising members of the genus Saccharopolyspora. Strains I05-00051, I05-00074 ${ }^{\mathrm{T}}$ and I0300808 showed less than $97.0 \% 16 \mathrm{~S}$ rRNA gene sequence similarity to the type strains of all recognized species of the genus Saccharopolyspora, with the exception of S. hirsuta subsp. hirsuta DSM $43463^{\mathrm{T}}(98.1 \%)$ and S. spinosa DSM $44228^{\mathrm{T}}(98.0 \%)$. Levels of DNA-DNA hybridization among strains I05-00051, I05-00074 ${ }^{\mathrm{T}}$ and $\mathrm{I} 03-00808$ were all above $70 \%$, while values between any one of these three strains and either S. hirsuta subsp. hirsuta DSM $43463^{\mathrm{T}}$ or S. spinosa DSM $44228^{\mathrm{T}}$ were significantly below $70 \%$ (see Supplementary Table S2 in IJSEM Online), the cut-off point recommended by Wayne et al. (1987) for the recognition of genomic species. Therefore, the three novel strains could not be classified as representing any of the recognized species of the genus Saccharopolyspora.

Morphological, physiological and chemotaxonomic similarities of the three new isolates combined with high levels of $16 \mathrm{~S}$ rRNA gene sequence similarity and DNA-DNA relatedness indicated that strains $\mathrm{I} 05-00051, \mathrm{I} 05-00074^{\mathrm{T}}$ and I03-00808 represent the same genomic species. The $\mathrm{G}+\mathrm{C}$ contents of the genomic DNA of strains I05-00051, I05-00074 ${ }^{\mathrm{T}}$ and I03-00808 were $68.2,69.3$ and $69.9 \mathrm{~mol} \%$, respectively.

Based on the phenotypic differentiation (Table 1) and genotypic data presented above, we consider that strains I05-00051, I05-00074 ${ }^{\mathrm{T}}$ and I03-00808 represent a novel species of the genus Saccharopolyspora. In view of their antimicrobial activities towards Staphylococcus aureus and E. coli, we propose the name Saccharopolyspora antimicrobica sp. nov. to accommodate these organisms.

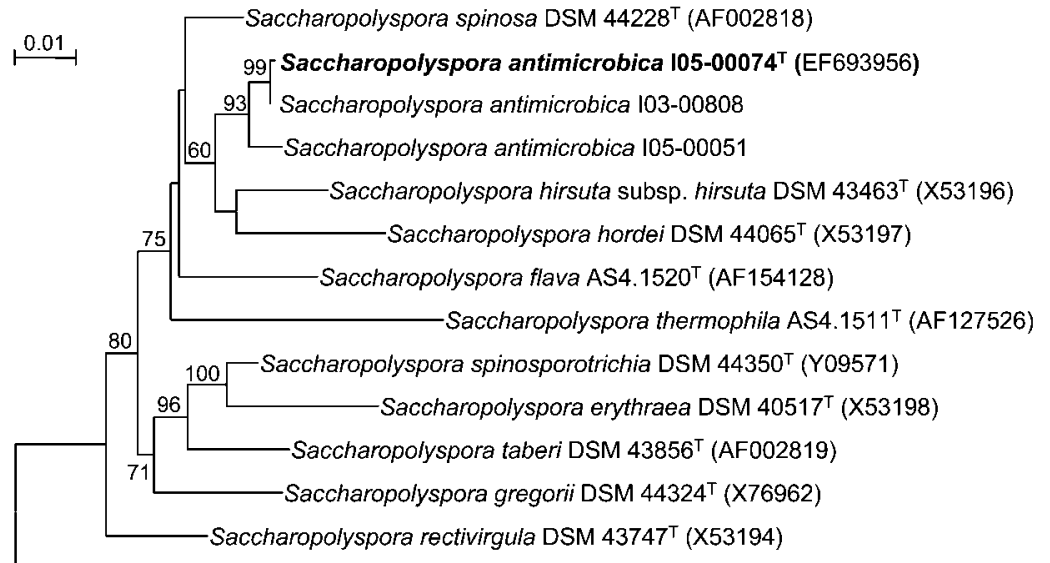

Actinopolyspora halophila ATCC $27976^{\top}$ (X54287)
Fig. 2. Neighbour-joining tree showing the phylogenetic relationships among strains 105$00074^{\top}, 105-00051$ and 103-00808 and the type strains of related taxa based on 16S rRNA gene sequences. Numbers at branch nodes are bootstrap values (percentages of 1000 replicates). Bar, 1 nt substitution per $100 \mathrm{nt}$. 


\section{Description of Saccharopolyspora antimicrobica sp. nov.}

Saccharopolyspora antimicrobica (an.ti'mi.cro.bi.ca. Gr. prep. anti against; N.L. n. microbium microbe; L. adj. suff.-cus $-a-$ um suffix used with various meanings; N.L. fem. adj. antimicrobica antimicrobial).

Aerobic, Gram-positive, non-acid-alcohol-fast, non-motile actinomycete. Good growth occurs on ISP 2, ISP 3, ISP 4, ISP 5, Czapek's agar, nutrient agar and potato agar media. Forms extensively branched, white, buff to pink substrate mycelia that later fragment into rod-shaped elements that carry aerial hyphae that differentiate into long chains of rough-surfaced spores. White aerial hyphae are produced upon cultivation on ISP 2 agar. Diffusible pigments, buff, pink to brown, are produced on some agar media. Adenine, hypoxanthine, tyrosine, casein, xylan, starch and gelatin are degraded, but cellulose, chitin, elastin and xanthine are not. Milk is coagulated and peptonized. Aesculin and urea are hydrolysed, nitrate is reduced, but $\mathrm{H}_{2} \mathrm{~S}$ is not produced. Utilizes adonitol, cellobiose, fructose, galactose, glucose, inositol, lactose, L-arabinose, melezitose, maltose, mannitol, raffinose, salicin, sorbitol, sucrose, xylose, acetate, citrate, malonate, phenylalanine, rhamnose, sorbitol, glyconate, dulcitol, mannose, D-ribose, turanose, melibiose, glucosamine and tartrate as sole carbon sources for energy and growth but does not use trehalose, erythritol or methyl $\alpha$-D-glucoside. Is able to produce $\beta$-glucosaccharase, $\alpha$-glucosaccharase, $\beta$-galactosidase, $N$-acetylglucosaminidase, alkaline phosphatase and acid phosphatase. $\mathrm{NaCl}$ tolerance range is $0-7 \%(\mathrm{w} / \mathrm{v})$. Temperature and $\mathrm{pH}$ ranges for growth are $20-45{ }^{\circ} \mathrm{C}$ and $\mathrm{pH} 6.0-8.5$, respectively. Optimal temperature and $\mathrm{pH}$ for growth are 28 $37^{\circ} \mathrm{C}$ and $\mathrm{pH} 7.0-7.5$, respectively. Growth is inhibited by lysozyme. Resistant $\left(\mu \mathrm{g} \mathrm{ml}^{-1}\right.$ ) to cefotaxime (30), aztreonam (30), amikacin (30), streptomycin (10), oxacillin (1), tobramycin (10), ceftazidime (30), gentamicin (10), erythromycin (15), chloromycetin (30), ampicillin (10), furadantin (300) and penicillin G (10 U). Shows antimicrobial activities against Staphylococcus aureus and E. coli. Contains meso-diaminopimelic acid and mainly arabinose and galactose in whole-organism hydrolysates. Phospholipids are diphosphatidylglycerol, phosphatidylcholine, phosphatidylglycerol and phosphatidylinositol. The predominant menaquinone is MK- $9\left(\mathrm{H}_{4}\right)$. The major fatty acids are iso- $\mathrm{C}_{15: 0}$, iso- $\mathrm{C}_{16: 0}$, iso- $\mathrm{C}_{17: 0}$ and anteiso$\mathrm{C}_{17: 0}$. The $\mathrm{G}+\mathrm{C}$ content of the genomic DNA is $69.3 \mathrm{~mol} \%$ for the type strain.

The type strain, $\quad$ I05- $00074^{\mathrm{T}} \quad\left(=\mathrm{CCM} \quad 7463^{\mathrm{T}}=\mathrm{KCTC}\right.$ $\left.19303^{\mathrm{T}}\right)$, was isolated from soil from the Temple of Heaven, Beijing, China. Strains I05-00051 and I03-00808, isolated from soil samples, are reference strains.

\section{Acknowledgements}

This research was supported by the National Facilities and Information Infrastructure for Science and Technology (grant number 2006DKA21203) and National Natural Science Foundation of China (Project no. 30600001). W.-J. L. was also supported by the New Century Excellent Talent (NCET) programme of Yunnan University.

\section{References}

Chun, J., Lee, J.-H., Jung, Y., Kim, M., Kim, S., Kim, B. K. \& Lim, Y. W. (2007). EzTaxon: a web-based tool for the identification of prokaryotes based on 16S ribosomal RNA gene sequences. Int J Syst Evol Microbiol 57, 2259-2261.

Collins, M. D. (1985). Isoprenoid quinone analysis in classification and identification. In Chemical Methods in Bacterial Systematics, pp. 267-287. Edited by M. Goodfellow \& D. E. Minnikin. London: Academic Press.

De Ley, J., Cattoir, H. \& Reynaerts, A. (1970). The quantitative measurement of DNA hybridization from renaturation rates. Eur $J$ Biochem 12, 133-142.

Embley, T. M., Wait, R., Dobson, G. \& Goodfellow, M. (1987). Fatty acid composition in the classification of Saccharopolyspora hirsuta. FEMS Microbiol Lett 41, 131-135.

Embley, T. M., Rostron, J., O'Donnell, A. G. \& Goodfellow, M. (1988). Chemotaxonomy of wall IV actinomycetes lacking mycolic acids. J Gen Microbiol 134, 953-960.

Felsenstein, J. (1985). Confidence limits on phylogenies: an approach using the bootstrap. Evolution 39, 783-791.

Goodfellow, M., Lacey, J., Athalye, M., Embley, T. M. \& Bowen, T. (1989). Saccharopolyspora gregorii and Saccharopolyspora hordei: two new actinomycete species from fodder. J Gen Microbiol 135, 2125-2139.

Kämpfer, P. \& Kroppenstedt, R. M. (1996). Numerical analysis of fatty acid patterns of coryneform bacteria and related taxa. Can J Microbiol 42, 989-1005.

Kimura, M. (1980). A simple method for estimating evolutionary rates of base substitutions through comparative studies of nucleotide sequences. J Mol Evol 16, 111-120.

Kimura, M. (1983). The Neutral Theory of Molecular Evolution. Cambridge: Cambridge University Press.

Korn-Wendisch, F., Kempf, A., Grund, E., Kroppenstedt, R. M. \& Kutzner, H. J. (1989). Transfer of Faenia rectivirgula (Kurup and Agre 1983) to the genus Saccharopolyspora as Saccharopolyspora rectivirgula comb. nov. and emended genus description of Saccharopolyspora. Int $J$ Syst Bacteriol 39, 430-441.

Kumar, S., Tamura, K., Jakobsen, I. B. \& Nei, M. (2001). MEGA2: molecular evolutionary genetics analysis software. Bioinformatics 17, 1244-1245.

Labeda, D. P. (1987). Transfer of the type strain of Streptomyces erythraeus (Waksman 1923) Waksman and Henrici 1948 to the genus Saccharopolyspora Lacey and Goodfellow 1975 as Saccharopolyspora erythraea sp. nov., and designation of the neotype strain for Streptomyces erythraeus. Int J Syst Bacteriol 37, 19-22.

Labeda, D. P. \& Kroppenstedt, R. M. (2000). Phylogenetic analysis of Saccharothrix and related taxa: proposal for Actinosynnemataceae fam. nov. Int J Syst Evol Microbiol 50, 331-336.

Lacey, J. \& Goodfellow, M. (1975). A novel actinomycete from sugar cane bagasse: Saccharopolyspora hirsuta gen. et sp. nov. J Gen Microbiol 88, 75-85.

Lechevalier, H. \& Lechevalier, M. P. (1965). Classification of aerobic actinomycetes based on their morphology and their chemical composition. Ann Inst Pasteur (Paris) 108, 662-673 (in French).

Lechevalier, M. P. \& Lechevalier, H. A. (1980). The chemotaxonomy of actinomycetes. In Actinomycete Taxonomy, pp. 227-291. SIM 
Special Publication no. 6. Edited by A. Dietz \& D. W. Thayer. Fairfax, VA: Society for Industrial Microbiology.

Lechevalier, M. P., De Bièvre, C. \& Lechevalier, H. A. (1977), Chemotaxonomy of aerobic actinomycetes: phospholipid composition. Biochem Syst Ecol 5, 249-260.

Li, W. J., Xu, P., Schumann, P., Zhang, Y. Q., Pukall, R., Xu, L. H., Stackebrandt, E. \& Jiang, C. L. (2007). Georgenia ruanii sp. nov., a novel actinobacterium isolated from forest soil in Yunnan (China) and emended description of the genus Georgenia. Int J Syst Evol Microbiol 57, 1424-1428.

Lu, Z., Liu, Z., Wang, L., Zhang, Y., Qi, W. \& Goodfellow, M. (2001). Saccharopolyspora flava sp. nov. and Saccharopolyspora thermophila sp. nov., novel actinomycetes from soil. Int J Syst Evol Microbiol 51, 319-325.

Marmur, J. \& Doty, P. (1962). Determination of base composition of deoxyribonucleic acid from its denaturation temperature. J Mol Biol 5, 109-118.

Mertz, F. P. \& Yao, R. C. (1990). Saccharopolyspora spinosa sp. nov. isolated from soil collected in a sugar mill rum still. Int J Syst Bacteriol 40, 34-39.

Minnikin, D.E., O’Donnell, A. G., Goodfellow, M., Alderson, G., Athalye, M., Schaal, A. \& Parlett, J. H. (1984). An integrated procedure for the extraction of isoprenoid quinones and polar-lipids J Microbiol Methods 2, 233-241.

Saitou, N. \& Nei, M. (1987). The neighbor-joining method: a new method for reconstructing phylogenetic trees. Mol Biol Evol 4, 406-425.

Sasser, M. (1990). Identification of Bacteria by Gas Chromatography of Cellular Fatty Acids, MIDI Technical Note 101. Newark, DE: MIDI Inc.

Shirling, E. B. \& Gottlieb, D. (1966). Methods for characterization of Streptomyces species. Int J Syst Bacteriol 16, 313-340.

Thompson, J. D., Gibson, T. J., Plewniak, F., Jeanmougin, F. \& Higgins, D. G. (1997). The CLUSTAL_X windows interface: flexible strategies for multiple sequence alignment aided by quality analysis tools. Nucleic Acids Res 25, 4876-4882.

Waksman, S. A. (1961). The Actinomycetes, vol. 2. Baltimore: Williams \& Wilkins.

Wayne, L. G., Brenner, D. J., Colwell, R. R., Grimont, P. A. D., Kandler, O., Krichevsky, M. I., Moore, L. H., Moore, W. E. C., Murray, R. G. E. \& other authors (1987). International Committee on Systematic Bacteriology. Report of the ad hoc committee on reconciliation of approaches to bacterial systematics. Int J Syst Bacteriol 37, 463-464.

Zhou, Z. H., Liu, Z. H., Qian, Y. D., Kim, S. B. \& Goodfellow, M. (1998). Saccharopolyspora spinosporotrichia sp. nov., a novel actinomycete from soil. Int J Syst Bacteriol 48, 53-58. 